\title{
Ecosystem Value Creation and Capture: A Systematic Review of Literature and Potential Research Opportunities
}

\author{
Behrooz Khademi
}

\author{
"Creating value is an inherently cooperative process, capturing value is \\ inherently competitive." \\ Barry Nalebuff \\ Professor of Management \\ Yale School of Management
}

\begin{abstract}
Collaboration, co-creation, and competition are essential strategies for success in today's modern businesses. In comparison with former ways of doing business in isolation, ecosystems nowadays have created ample opportunities for generating significantly more values. However, there are also potential threats in the pathway towards success in ecosystems. Ecosystem value creation and capture (EVCC) has recently gained significant attention in the academic literature of business and management. Yet, due to the complex structures of ecosystems and ambiguity in understanding value creation and capture in ecosystems, the contributions heretofore are fragmented, where scholars analysed different aspects of EVCC. The present study offers a systematic review of the literature to shed light on the EVCC studies. The content analysis of a fine-grained sample of articles relevant to EVCC revealed that despite the initiation of discussions in 2007, the topic did not gain noticeable attention until 2016. A $150 \%$ increase in the number of papers has since been observed. The paper contributes to the intersection of strategy and studies on EVCC by synthesizing existing knowledge, illuminating current EVCC research, and highlighting potential research avenues.
\end{abstract}

\section{Introduction}

The number of papers emphasizing the importance of value creation and capture in ecosystems and collaborative networks has been growing. Especially, the growth has been more noticeable since 2016, with a $150 \%$ increase in papers published. However, the contributions are mainly fragmented, where scholars have addressed different themes involving 'ecosystem value creation and capture' (EVCC). Reasons for such fragmentation could include a lack of adequate understanding of the concepts in collaborative networks of innovative organizations (Chesbrough, et al., 2018), complexity of interactions in ecosystems (Ben Letaifa, 2014; Ritala \& Almpanopoulou, 2017), and overall ambiguity in the exact structure of ecosystems (Ben Letaifa, 2014; Ritala \& Gustafsson, 2018). Furthermore, as it pertains to collaborative networks of innovative firms, the concepts of 'value creation' and 'value capture' have been addressed with ambiguities regarding value perspectives (Chesbrough et al., 2018). Therefore, it is essential to comprehensively analyse EVCC in the academic literature.
'Ecosystem' is a metaphor from the field of ecology, suggested by Moore (1993) to describe the complex, dynamically changing, symbiotic relationships formed among a network of business organizations. 'Value creation' and 'value capture' have been debated conceptually in the fields of marketing, strategic management, industrial organizations, and business models (Chesbrough et al., 2018; Pitelis, 2009). The 'ecosystem value creation' process is regarded as a mechanism for collaboration and activities within an ecosystem to create value for customers and users (Hannu Tuomisaari et al., 2013). 'Ecosystem value capture' refers to firm-level strategic plans that appropriate their share of the total value created by an ecosystem (Hannu Tuomisaari et al., 2013), be it captured purposely or serendipitously (Radziwon, et al., 2017; Ritala et al., 2013). EVCC is an integral part of ecosystem business models (Ceccagnoli et al., 2012) and the sustainability of ecosystems (Chesbrough et al., 2018). It serves to dynamically monitor contributions of actors to the proposed collective value, while determining their share of the total appropriated value.

The research questions (RQs) leading this paper are as follows: 


\section{Ecosystem Value Creation and Capture: A Systematic Review of Literature and Potential Research Opportunities Behrooz Khademi}

\section{RQ1: How have EVCC studies grown and changed over time in the literature? \\ RQ2: What are the underlying research themes in EVCC studies? \\ RQ3: What are the potential opportunities for future research in EVCC?}

The remainder of this paper is structured as follows: The next section describes the research method used to collect data and answer the RQs. The subsequent section presents the results of the analyses and a response to each of the RQs. The paper ends by summarizing the results, highlighting the contributions of the study, and pointing out the limitations in conducting the research.

\section{Research Method}

The study follows a standard systematic literature review. This section describes the sampling process (conducted in early 2019) used to identify the relevant literature as well as the steps undertaken to answer each of the RQs.

\subsection{Identifying the literature 2.1.1. Choice of Database}

Web of Science (WoS) was the preferred database to search the literature for several reasons. First, compared to other databases such as Google Scholar, WoS provides the highest number of high quality journals and articles (as cited in Scaringella \& Radziwon, 2017) and reliability (Augillo and Falagas, as cited in Prins et al., 2016). Second, Gavel and Iselid (2008) quantitatively showed that the coverage of WoS in social science and humanities is broader than SCOPUS. Third, according to these authors, WoS has a longer time span and citation coverage in comparison with SCOPUS.

\subsubsection{Search Rules and Initial Article Extraction}

To identify the initial pool of articles to be reviewed, a synthesis of keywords such as "ecosystem", "value creation", "value co-creation", "value capture", and "value appropriation" were used in two rounds based on the following search rules:

- ecosystem AND ("value creation" OR "value cocreation"),

- ecosystem AND ("value capture" OR "value appropriation").

The first rule identified 313 articles, while the second rule resulted in 32 articles.

\subsubsection{Paper Selection and Sample Screening}

For this study, only high-quality papers pertinent to EVCC in business and management scholarship and in English language were of interest. As only high-quality papers were of interest, the search was limited to refereed journal articles in WoS. The search process identified 171 unique articles (after removing duplicate results from the two different search rules) at the preliminary step.

The preliminary sample had to be screened for context and content relevance. For value creators, continuous satisfaction of customers must be the main target. This is irrespective of whether the offer is collectively presented or if solutions are offered by an individual enterprise (Bowman, as cited in Hannu Tuomisaari et al., 2013). EVCC includes optimizing, preventive, and radically innovative approaches for efficiency maximization and differentiation in ecosystems. Such approaches are essential for an entity (or a constellation of entities) to be able to create and capture higher value. Based on such an understanding from EVCC, irrelevant papers were excluded from the preliminary sample of articles.

The titles, abstracts and conclusions of the papers were thoroughly analysed. Findings where ecosystem was applied as a 'buzzword', 'wrong metaphor' or 'irrelevant analogy', without being considered as the proper unit of analysis (Aarikka-Stenroos \& Ritala, 2017; Ritala \& Almpanopoulou, 2017; Suominen et al. 2019), were excluded from the sample. Similarly, those studies that tested non-technological contexts in service ecosystems or marketing studies were removed from the sample (See Scaringella and Radziwon (2017) for the same approach). The sample was shrunk to 50 papers after this stage.

\subsubsection{Sample refinement}

It was found out that some other studies in the reference list of the papers in the shrunk sample $(\mathrm{N}=50)$ were relevant to EVCC but they had not appeared in the preliminary search phase. One reason is that author keywords were not used in some of the papers relevant to EVCC, hence those papers were not listed in the initial search attempt in WoS. Examples include papers from R\&D Management, Journal of Product Innovation Management, Strategic Management Journal, and Technology Innovation Management Review. Therefore, adding the most relevant papers in the backward citations list, the shrunk sample was complemented to increase the percentage of recall for the sample (the measure used to indicate the share of the number of papers in a sample from all possible number of papers in 


\section{Ecosystem Value Creation and Capture: A Systematic Review of Literature and Potential Research Opportunities Behrooz Khademi}

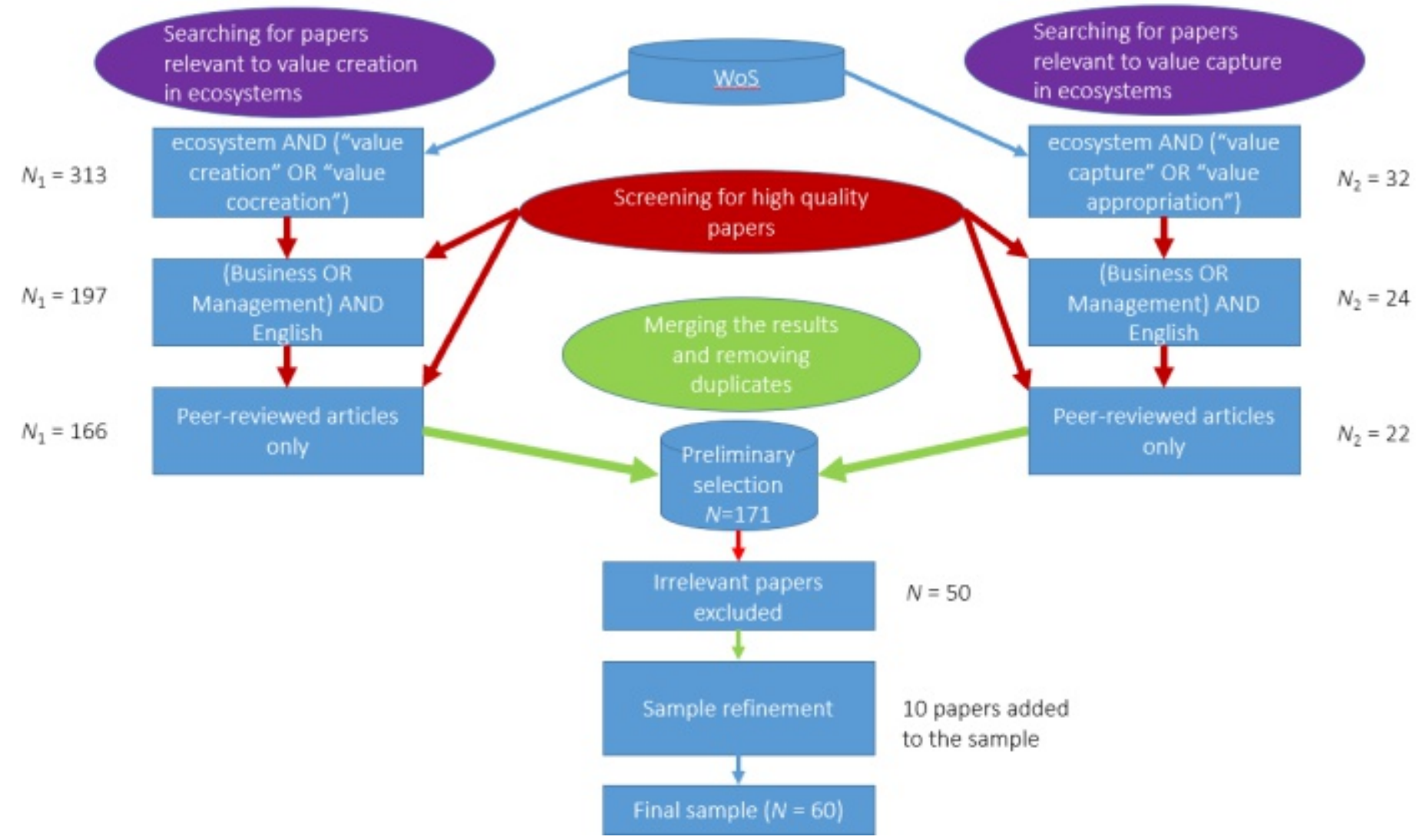

Fig. 1. Step-by-step sampling process

the sample) and a more precise content analysis (See Takey and Carvalho, 2016, for an example of such an approach in sample refinement).

The same quality screening criteria (only relevant and English journal articles in the WoS database) were applied in the sample refinement phase. Applying this strategy, 10 more papers were added to the sample. In total, the final sample consisted of 60 papers, which formed the foundation of the content analysis. Fig. 1 describes the step-by-step sampling process.

\subsection{Data analysis}

Descriptive statistics of the sample used for observing the trend in popularity and trajectory of EVCC studies in the relevant literature, i.e., for responding RQ1. Next, content analysis was conducted and all the 60 papers of the sample were carefully analysed to explore the main themes discussed heretofore in the scholarly research of EVCC (response to RQ2). The sample was not too large and for higher precision, text mining was not applied for theme exploration. The content analysis provided the required input for identifying the research puzzles in the literature of ecosystem studies and EVCC, thereby responding to RQ3.

\section{Results}

\subsection{Trajectory of EVCC using descriptive statistics of the final sample}

The final sample $(\mathrm{N}=60)$ was analysed according to the year of publication to explore the publishing trend in EVCC. Despite a fall in 2015, there has been an upward trend in publishing papers on EVCC since 2012. However, the growth is more notable since 2016, with 36 papers $(60 \%$ of the sample and a $150 \%$ increase of the sample size), out of which 16 papers (26.7\%) were published in 2018 (See Fig. 2).

Table 1 lists the 13 authors (first author or co-author) in the sample with more than one paper. From all 142 authors in the sample, Annabelle Gawer and Paavo Ritala had the highest number of contributions in the final sample.

Fig. 3 illustrates the number of papers per authors' affiliation in the final sample for the top 25 organizations. As can be seen, scholars affiliated at 


\section{Ecosystem Value Creation and Capture: A Systematic Review of Literature and Potential Research Opportunities Behrooz Khademi}

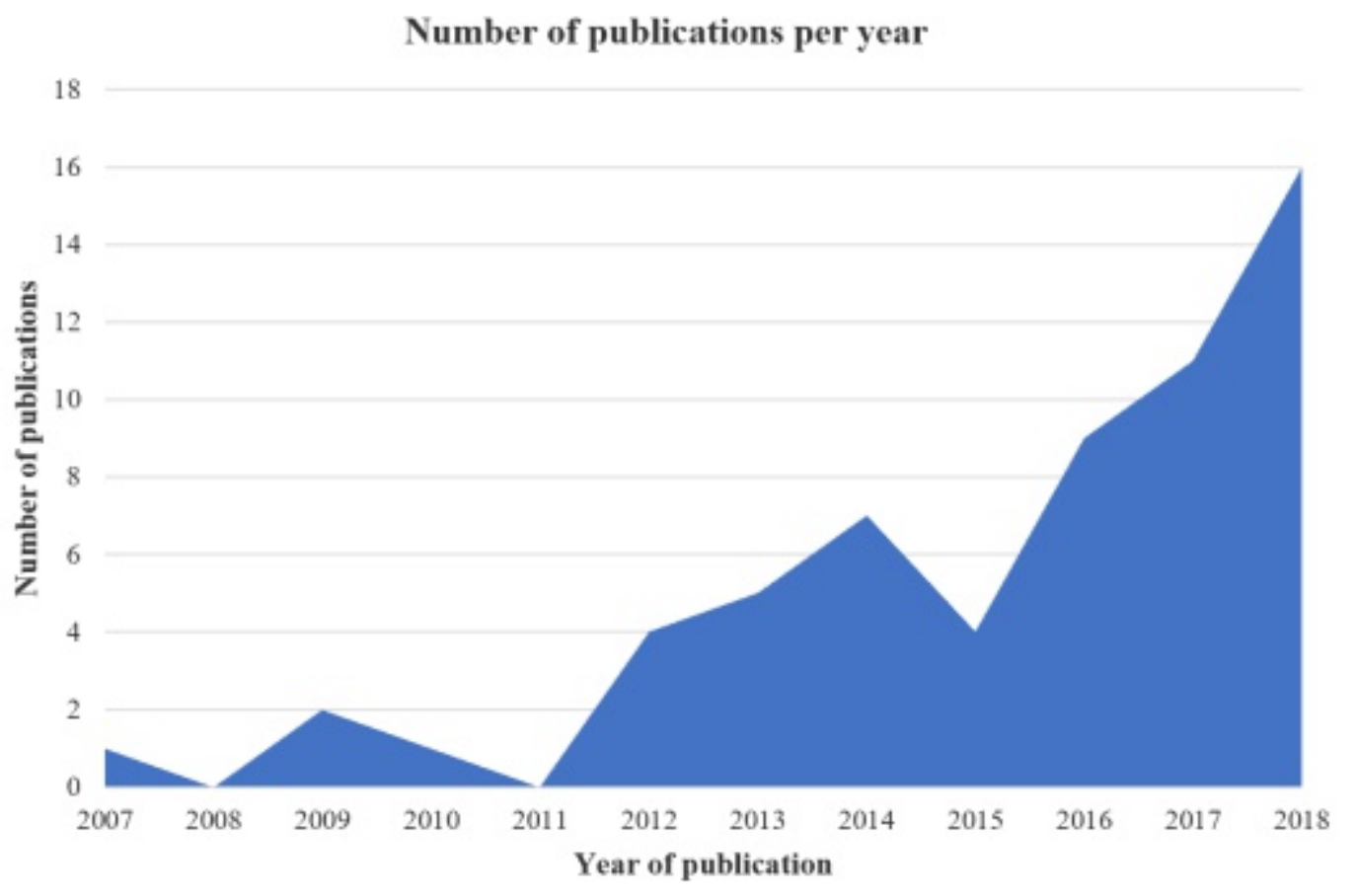

Fig. 2. Number of publications per year for the final sample of articles $(N=60)$

American, British, and Finnish organizations have engaged the most in EVCC research.

Table 2 details the number of papers per each source title in the sample. According to the results, International Journal of Technology Management, Research Policy, Technological Forecasting \& Social Change, and Technology Innovation Management Review were the top four popular journals among the scholars.

\subsection{Major research themes emerging from content analysis}

The findings of the content analysis were classified into four categories according to the emerging research themes: mechanisms of EVCC, drivers of EVCC, challenges of actors for EVCC, and effective strategies and operational practices for EVCC. Below, scholarly research in each of the themes is highlighted.

\subsubsection{Mechanisms of EVCC}

While ecosystem value creation requires collaboration, ecosystem value capture forces firms to protect themselves. This "paradox of openness" (Laursen \& Salter, 2014) makes understanding the mechanisms of EVCC complex. Not only are the mechanisms for value creation different from those for value capture, but also the mechanisms of EVCC differ from one type of ecosystem to another. Such differences stem from their unique mutual intentions ("baselines"), players in the ecosystem, their roles, interactions between players, and the logic of action (Valkokari, 2015). Different

Table 1. Authors with more than one paper in the final sample

\begin{tabular}{ll}
\hline \hline Authors & $\begin{array}{l}\text { Number of } \\
\text { Papers }\end{array}$ \\
\hline Annabelle Gawer, Paavo Ritala & 3 \\
$\begin{array}{l}\text { Ron Adner, Rahul Kapoor, Michael Jacobides, Katri Valkokari Carmelo } \\
\text { Cennamo, Jens Dibbern, Shaz Ansari, Raghu Garud, Arun Kumaraswarmy, } \\
\text { Thomas Kude, Christopher Lettl }\end{array}$ & 2 \\
\hline
\end{tabular}




\section{Ecosystem Value Creation and Capture: A Systematic Review of Literature and Potential Research Opportunities Behrooz Khademi}

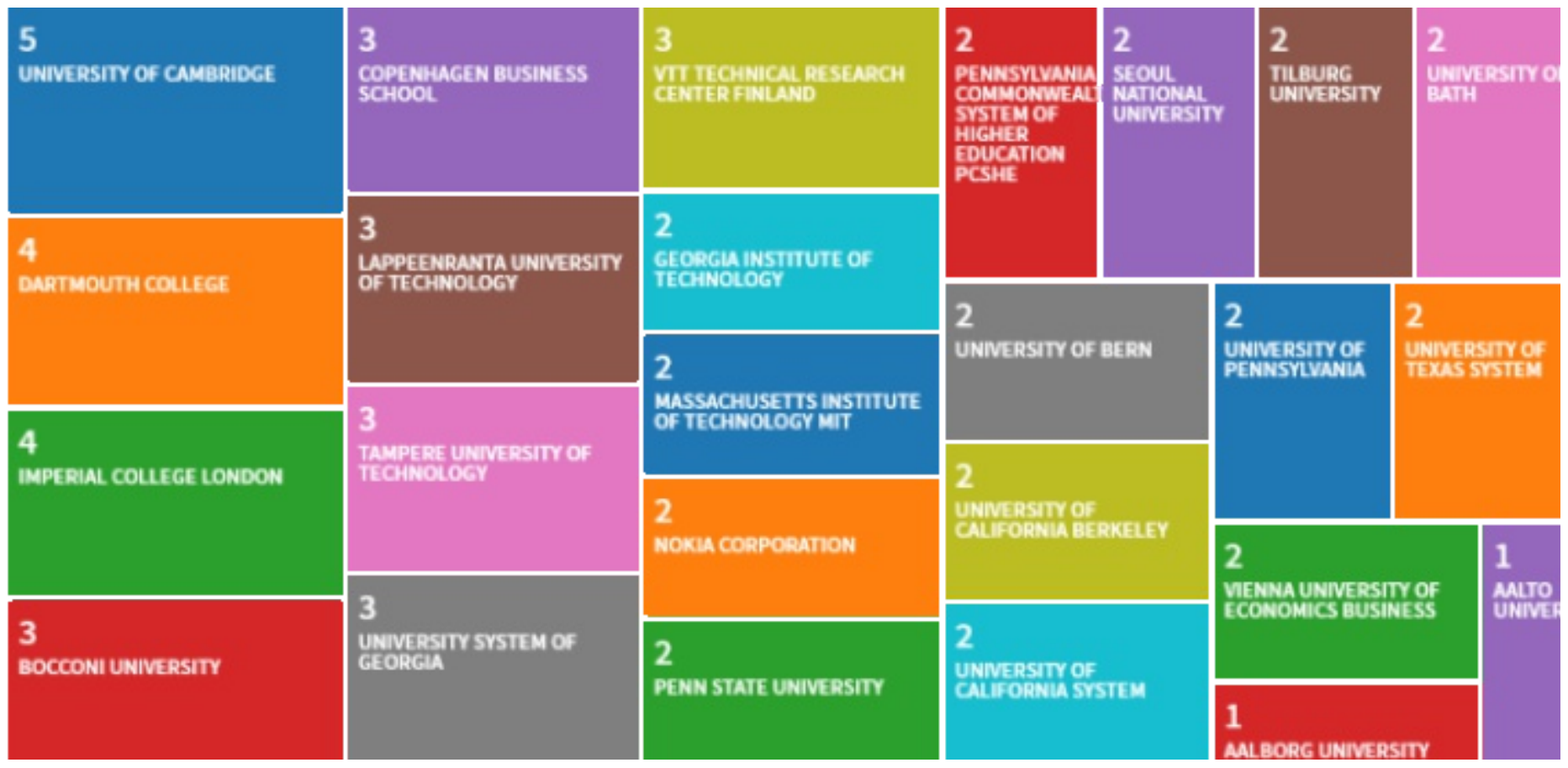

Fig. 3. Number of papers per authors' affiliation for the top 25 organizations

mechanisms of EVCC can be the result of differences in complementarities; direction of relationships, symmetry or asymmetry of the effect location, and modularity of ecosystems (Jacobides, Cennamo, \& Gawer, 2018). Fig. 4 depicts the determinants for different mechanisms of EVCC.

Business ecosystems consist of focal actors, suppliers, complementors, and users. The interaction between actors are non-linear and geographical boundaries do not limit the operations of the business ecosystem. Cocreation and co-capture of value are mainly realized through resource exploitation (as a shared intention), coopetition (Dagnino \& Padula, 2002), and provision of a unique platform by a focal actor for complementarities (Valkokari, 2015). Platforms and developers play a crucial role in value creation involving creative industries and business ecosystems (Parker et al., 2017). The co-created value is cocaptured through sharing (distributing) the revenue among business ecosystem members (Oh et al., 2015). A decent appropriability regime is therefore essential in ecosystems to ensure of the realization of value capture (Ceccagnoli et al., 2012; Oh et al., 2015).

Knowledge ecosystems are comprised of universities, research centres, and entrepreneurs. Co-exploration of new knowledge in decentralized networks is the mutual objective of actors, assisted by innovation intermediaries, and by co-innovation within defined geographical clusters (Valkokari, 2015). Having said that, the new definition for knowledge ecosystems indicates the increasing blurriness of spatial boundaries and nowadays, knowledge ecosystems are operating in a more global scale (Järvi et al., 2018). Unlike in business and innovation ecosystems, focal actors in knowledge ecosystems (universities and research centres) are not involved in direct competitions (Clarysse et al., 2014). Furthermore, the value creation process in knowledge ecosystems is a linear process with the flow moving from upstream to downstream actors (Clarysse et al., 2014). Depending on whether a knowledge ecosystem specializes in a knowledge domain or is still in pursuit of one, EVCC mechanisms can differ. In the former case known as 'partial forms', more formal mechanisms for membership and access to knowledge and resources are common, whereas in the latter case known as 'prefigurative forms', less formal and more voluntary mechanisms are used (Järvi et al., 2018). In the same vein, value capture mechanisms in knowledge ecosystems differ according to the technology lifecycle. Less formal IP strategies such as secrecy are more common in pre-development phases, whereas more formal strategies such as patenting are used near the beginning of the development phase (Toma et al., 2018).

The main actors of innovation ecosystems, the lead producers, suppliers, competitors, policy makers, 


\section{Ecosystem Value Creation and Capture: A Systematic Review of Literature and Potential Research Opportunities Behrooz Khademi}

Table 2. Number of papers in the final sample per publication

\begin{tabular}{ll}
\hline Source Title & Number \\
International Journal of Technology Management & 6 \\
Research Policy, Technological Forecasting \& Social Change, Technology & 5 \\
Innovation Management Review & \\
California Management Review, Strategic Management Journal, Journal of & 4 \\
Product Innovation Management & 3 \\
MIS Quarterly & 2 \\
Organization Science, Electronic Markets, Journal of Management Studies & 1 \\
Academy of Management Journal, Advances in Strategic Management, \\
Business Process Management, Creativity and Innovation Management, \\
European Journal of Information Systems, European Management Review, \\
IEEE Transactions on Engineering Management, Information Systems \\
Research, International Entrepreneurship and Management Journal, \\
$\begin{array}{l}\text { International Journal of Innovation Science, International Journal of } \\
\text { Innovation and Technology Management, Journal of Information Technology, } \\
\text { Journal of Management, Management Decision, Management Science, R\&D } \\
\text { Management, Technology Analysis and Strategic Management, Technovation }\end{array}$ \\
\hline
\end{tabular}

intermediators and public and private funding agencies, are geographically bounded in innovation hubs. Actors and their interdependencies, activities, positions and links are the main constructs of innovation ecosystems (Adner, 2016). In lieu of incremental improvements, focal actors are keen (together with their long-term partners) on co-inventing radically new and nonreplicable solutions (Ritala et al., 2013; Valkokari, 2015). Value creation process in innovation ecosystems is described dynamically from the "building" phase to "management" (Ritala et al., 2013), where the mechanism becomes clearer over time (Ben Letaifa, 2014; Chen et al., 2016; Ritala et al., 2013). Similar to value creation, value capture is a dynamic process in innovation ecosystems. In fact, for effective value capture, an actor needs not only the ability to capture a share of the collectively created value, but also the ability to capture value through other actors' efforts in further stages of value creation (Chesbrough et al., 2018).

\subsubsection{Drivers of EVCC}

Four major drivers that influence EVCC in ecosystems were identified in the content analysis: ecosystem attractiveness, efficient architecture and platform design, proper management of intellectual properties (IPs), and government intervention. Fig. 5 represents a visualisation for the major drivers of EVCC.

\section{Ecosystem attractiveness}

The literature review identified ecosystem attractiveness as one of the main drivers of EVCC. Value maximization and risk minimization were regarded as the two major incentives for actors to join ecosystems. Maximizing financial value (Chesbrough \& Appleyard,
2007; Herskovits et al., 2013), having competitive advantage and higher degree of innovativeness (Herskovits et al., 2013; Luo \& Triulzi, 2018; Mäkinen et al., 2014), and creating social value (Fulgencio, 2017) are the main incentives for ecosystem partnerships. Reduction of risks and uncertainty impacts also has a positive outcome in ecosystems, such as leading to higher motivation for external complementarities, cost reduction, more consistent and trustful knowledge sharing, and ecosystem differentiation (Williamson \& De Meyer, 2012).

\section{Efficient architecture and platform design}

Standardization of platforms enables better access to partners' knowledge and resources and thus to better EVCC (Tura et al., 2018). In addition, a proper and explicitly designed platform allows firms to grow more symbiotically and systematically ( $\mathrm{Li}, 2009)$. The application of a wrong ecosystem architecture per se can lead to failure of the ecosystem. Therefore, considering the ecosystem architecture at all stages of the conceptual platform design is paramount (Tee \& Gawer, 2009).

\section{Proper management of IP}

Proper IP management by ecosystem orchestrators not only positively affects their captured value, but also increases the entire EVCC (Azzam et al., 2017; Leten et al., 2013). Therefore, R\&D investments for smart selection and implementation of appropriability mechanisms are essential, which in turn helps to minimize negative effects of spillovers, and also to maximize R\&D productivity (Teece, 2018). Furthermore, focal firms can allow complementors to use their IPs to develop their own technologies in new markets as well 


\section{Ecosystem Value Creation and Capture: A Systematic Review of Literature and Potential Research Opportunities Behrooz Khademi}

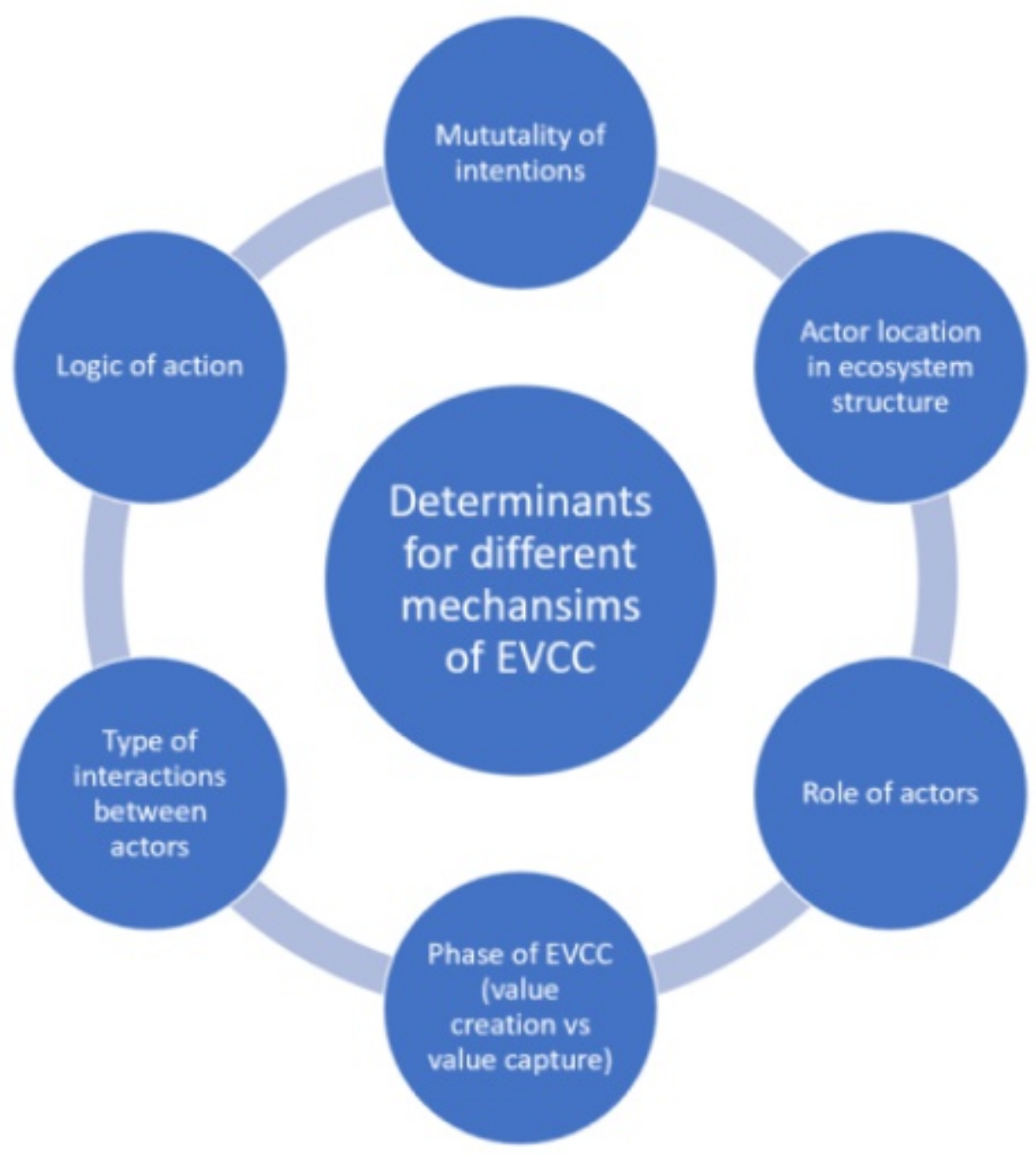

Fig. 4. Determinants for different mechanisms of EVCC

as generate new and diversified sources of revenue for their ecosystem (Azzam et al., 2017).

\section{Government intervention}

Government intervention by means of supportive funding plans and regulatory policies also often affects EVCC. External funds and common objectives of regional knowledge and innovation ecosystem actors have proven to have a significantly positive influence on EVCC (Radziwon et al., 2017). However, funding regional knowledge ecosystems without proper commercialization plans does not necessarily culminate in shaping a network of industrial firms for better innovation output (Clarysse et al., 2014). In the absence of regional players that commercialize innovation outputs from knowledge ecosystems, governments can intervene by inspiring global technology players, investors, financial agencies, and crowd-funding to support regional knowledge ecosystems (Clarysse et al., 2014). City governments have a critical orchestrating role by providing integrated solutions for end customers and also of facilitating the interactions between ecosystem members through the making of local 'platform hubs' (Visnjic et al., 2016). Inconsistent decision-making in multi-layered governments, however, has a tendency to delay the potential value appropriation process of new technologies (Teece, 2018).

\subsubsection{Challenges for realization of EVCC}

Challenges for realizing EVCC have been discussed mainly with regard to innovation and business ecosystems. In innovation ecosystems, focal actors encounter challenges where applying certain strategies 


\section{Ecosystem Value Creation and Capture: A Systematic Review of Literature and Potential Research Opportunities Behrooz Khademi}

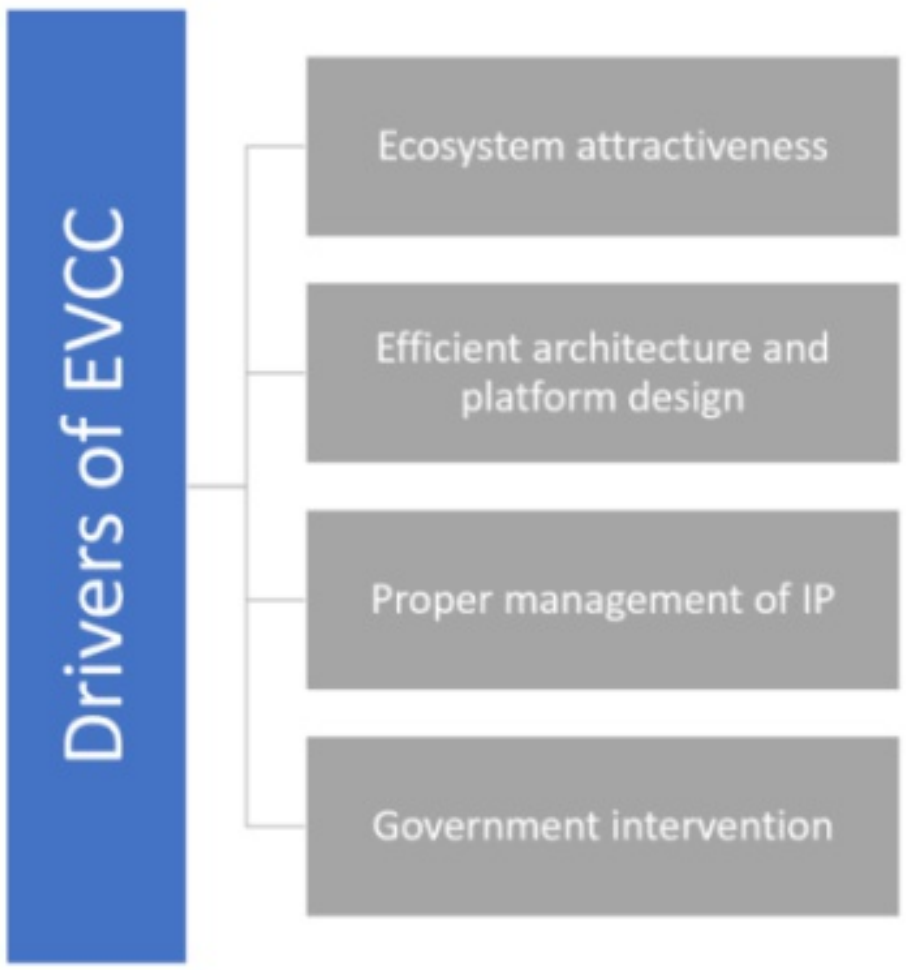

Fig. 5. Major drivers of EVCC

are essential to survive the ecosystem. Overlooking systematic partner selection in innovation ecosystems may result in serious consequences as radical changes in technologies and platforms are expected (Pellikka \& Ali-Vehmas, 2016). The effect of challenges with upstream and downstream sectors are asymmetric and unlike the positive effects of bottlenecks related to suppliers' delay in innovation, such bottlenecks emerging by complementors curb the speed of innovation for leaders (Adner \& Kapoor, 2010). Despite the positive effects of upstream bottlenecks for value creation, the risk of opportunistic behaviours by upstream sector for changing contracts in their favour is high. Although focal actors' complementary technologies may differentiate their platforms, it is likely that their core technology would permeate because of such disclosures and allow other players (with the same expertise) expropriate the focal technology (Toh \& Miller, 2017). Start-up companies face serious challenges in persuading incumbents for further support of technology development and commercialization (Ansari et al., 2016). The absence of ecosystem culture, improper or no orchestration mechanism and replacement of rivalry instead of competition are the main threats for innovation ecosystems (Ben Letaifa, 2014).
In business ecosystems, keystones must be mindful about domination and the extent of access to platforms by complementors. Domination has been known as a big challenge in ecosystems as it can make the ecosystem vulnerable and easier to fail (Tellier, 2017). Despite the benefits of 'kingpins' in industry segments, their presence and dominance increases the heterogeneity in value and $R \& D$ leadership within the segment over a long run (Jacobides \& Tae, 2015). Access of complementors to platforms owned by focal firms have been among the challenges in business ecosystems. In software ecosystems, access of complementors to the resources and knowledge of platform owners is essential for value co-creation. The motivation for open source software vendors is not benefiting from the product itself, but the complementary and intangible assets such as tacit knowledge and differentiation (Morgan et al., 2013). Despite success stories in open business models, their implementation and governance could be challenging (Huber et al., 2017). Attraction and retention of complementors, lack of innovation and support from complementors, and revenue generation are among those challenges (Chesbrough \& Appleyard, 2007). Table 3 concisely demonstrates the discussed challenges for ecosystem actors taking the location of actors (structure-wise) into account. 


\section{Ecosystem Value Creation and Capture: A Systematic Review of Literature and Potential Research Opportunities Behrooz Khademi}

Table 3. Challenges of ecosystem actors for realization of EVCC

\begin{tabular}{|c|c|c|}
\hline $\begin{array}{l}\text { Challenge } \\
\text { No }\end{array}$ & Challenge & $\begin{array}{l}\text { Actor } \\
\text { location }\end{array}$ \\
\hline 1 & Systematic partner selection & \multirow{8}{*}{$\begin{array}{l}\text { Focal } \\
\text { actors }\end{array}$} \\
\hline 2 & $\begin{array}{l}\text { Delay in complementary contributions to the major } \\
\text { platform }\end{array}$ & \\
\hline 3 & $\begin{array}{l}\text { Expropriation of focal technologies by other ecosystem } \\
\text { actors }\end{array}$ & \\
\hline 4 & Absence of ecosystem orchestration mechanisms & \\
\hline 5 & $\begin{array}{l}\text { Extent of complementors' access to the focal actor's } \\
\text { platform }\end{array}$ & \\
\hline 6 & Continuously attracting and retaining complementors & \\
\hline 7 & Lack of innovativeness in complementary contributions & \\
\hline 8 & Dangers of domination & \\
\hline 9 & $\begin{array}{l}\text { Persuasion of incumbents for supporting radically new } \\
\text { technologies }\end{array}$ & $\begin{array}{l}\text { Start-ups } \\
\text { and new } \\
\text { entrants }\end{array}$ \\
\hline 10 & Absence of ecosystem culture & \multirow{3}{*}{ All actors } \\
\hline 11 & $\begin{array}{l}\text { Replacing constructive competition (for better EVCC) } \\
\text { with destructive rivalry }\end{array}$ & \\
\hline 12 & Business models and revenue generation & \\
\hline
\end{tabular}

\subsubsection{Effective strategic and operational practices for EVCC}

Ecosystem business models and collective approaches towards characterizing roles and strategies for all actors are crucial (Borgh et al., 2012; Ikävalko et al., 2018; Papert \& Pflaum, 2017). Despite the criticality of orchestrating roles of keystones, a collective approach towards ecosystem orchestration with more flexible and extensible business models (Rong, Patton, \& Chen, 2018) is essential for improving EVCC (Valkokari, Seppanen, Mantyla, \& Jylha-Ollila, 2017), because ecosystems' constructs and interdependencies cannot be predicted ahead of time (Dattee, Alexy, \& Autio, 2018). Flexible and collective approaches in ecosystem business models support start-ups to manage uncertainties while developing radically innovative technologies (Vasconcelos et al., 2018). Invention of disruptive technologies and disruptors' entry stimulate the emergence of 'business model adaptation' and formation of ecosystem business models by incumbents to source external knowledge (Cozzolino et al., 2018). An ecosystemic approach towards cybersecurity enables identifying the major stakeholders, prioritizing risk mitigating plans, and creating more value for end customers (Tanev et al., 2015). In contrast, a "performative approach" collectively frames and reframes all the plans and joint activities within an ecosystem, giving an example of practices that offer firms flexibility and respond to uncertainties more efficiently (Kumaraswamy et al., 2018).

Applying certain strategies and practices in ecosystem business models can significantly enhance EVCC. Identifying and involving universities and research centres, integrating knowledge, and disseminating knowledge are considered as essential practices for enabling innovation ecosystems (Spena et al., 2016). Network visualization is an invaluable practice for identifying opportunities by extracting information on current interactions (Li, 2009; Still et al., 2014). In addition, dynamic capabilities support platform leaders (Helfat \& Raubitschek, 2018) and complementors (Ehrenhard et al., 2017) to overcome ecosystem challenges more effectively. Facilitating innovation processes in individual organizations and creating innovation communities (Hooge \& Le Du, 2016) serve to strengthen value creation in knowledge ecosystems (Borgh et al., 2012).

Essential strategies are required for focal firms prior to becoming an ecosystem leader. Leaders need to define a clear vision for the ecosystem, design a modular platform with open modules for other members' contributions, continuously monitor the relationships, make continuous innovations, and ensure the platform is always interesting for complementors (Pellikka \& Ali- 


\section{Ecosystem Value Creation and Capture: A Systematic Review of Literature and Potential Research Opportunities Behrooz Khademi}

Vehmas, 2016). Managers must also have a correct perception of the limits of their knowledge, the higher value of integrating intellectual properties, and the importance of the proposed value (Williamson \& De Meyer, 2012).

Platform leadership strategies have significant influence on EVCCs and ecosystem survival . Proper architecture that enables convenient interactions between players, control over the relationship with other ecosystem actors, and monitoring the competitiveness of the platforms is the responsibility of the platform leader (Helfat \& Raubitschek, 2018). But this is insufficient for success in the ecosystem game. Idea evaluation, partner selection and incentivization, making continuous improvements to core competencies, proper orchestration, continuous revision of business models, and adopting appropriate expansion strategies are among other keystone responsibilities (Gawer \& Cusumano, 2014). In order to expand an ecosystem's boundaries, mergers and acquisitions (M\&A) could be a helpful and effective strategy. A key success factor in M\&A is leaving the assignees' culture and employees virtually unchanged, while providing them with new leadership training, instead of recruiting a new labour force (Li, 2009). Vertical integration has been shown as a successful strategy in order to prevent the risk of opportunistic behaviour by firms in upstream sectors (Adner \& Kapoor, 2010).

Assessing partners before and during partnerships is paramount for all ecosystem actors. Assessing core competencies and the extent of internal complementary activities enables platform vendors to identify the need for complementarities, thereby informing the selection of the right partners (Kude et al., 2012). Setting up rules and unique practices for each dyad, as well as explicitly defining the optimum degree of openness (Parker et al., 2017), minimizes risks and provides co-creation of the maximum possible value (Huber et al., 2017). Keystone leaders must have appropriate strategies for attracting complementors under various market and dominance conditions (Mantovani \& Ruiz-Aliseda, 2016). However, focal actors must pay special attention to the risk of core technology disclosure. A higher degree of firm-complementor collaboration is possible only when the core technologies and competencies are distinct (Kapoor, 2013). Analysis of EVCC from the perspective of complementors and how they evaluate partnerships in ecosystems are crucial as they create a large share of value in ecosystems (Gawer \& Cusumano, 2014; Teece, 2018). Access to keystone resources and taking advantage of their innovativeness and reputation, enable complementors to help expand the firms production (Morgan et al., 2013). The main motivation for complementors to collaborate with platform leaders is to improve the platform's attractiveness and viability (Chesbrough et al., 2018; Morgan et al., 2013). Inputoriented views (resource motivation and hub capabilities) and output-oriented views (product-level complementarity) should be combined to evaluate the motivation of "spokes" for partnering with "hubs" (Kude et al., 2012).

In platform-based business ecosystems, it is crucial to pay special attention to retaining end-users (rather than complementors), reducing the application review time, and lowering the frequency of platform updates (Song et al., 2018). Diversity of users is one of the keys to success in value creation for platform ecosystems (Kim, 2016). System usability, service variety, and user connectivity influence user value (Haile \& Altmann, 2016). Beta products are essential for the competitiveness of a business ecosystem in a new product development phase (Mäkinen et al., 2014). Some platform leaders such as LEGO go even further to build sustainable producer-user ecosystems. Such ecosystems benefit from lower risks for entrepreneurship, increase in product lines and market segments, and higher level of awareness or "buzz" surrounding new ideas (Hienerth, Lettl, \& Keinz, 2014). Due to the heterogeneous behaviours and preferences of customers in platform lifecycles, complementors must contemplate different option strategies in the early stages, and develop the most successful ones afterwards (Rietveld \& Eggers, 2018). Table 4 demonstrates the effective strategies and practices for EVCC by taking various types into account.

\subsection{Potential avenues for future research}

Content analysis of the final sample shows that there are missing puzzle pieces in the literature of ecosystems and EVCC. This could signify potential for further research development.

\subsubsection{Empirical studies on non-focal actors for EVCC} Most research in ecosystems and EVCC is shaped around focal actors (Aarikka-Stenroos \& Ritala, 2017) and how they influence EVCC. Much less focus is on how complementors, policy makers, investors, startups, and intermediaries influence EVCC. Only a few studies drew on the role of innovation intermediaries, business incubators, and business accelerators (Carvalho \& Galina, 2015; Ngongoni, Grobbelaar, \& Schutte, 2017) in entrepreneurial ecosystems. For a 


\section{Ecosystem Value Creation and Capture: A Systematic Review of Literature and Potential Research Opportunities Behrooz Khademi}

more established concept, it is crucial to have a deeper understanding of all participating actors and how they operate in the ecosystem. For instance, it would be interesting to examine the ways ecosystems address the tensions among all actors as it pertains to cannibalization over resources. Thus, although radical innovation may create invaluable opportunities for ecosystems, it could also be in some ways challenging to actually benefit from the radical idea, since all partners in an ecosystem need to fully respond to a major change with respect to their various platforms and portfolios.

\subsubsection{Appropriability regimes in ecosystems}

In comparison with ecosystem value capture, scholars have focussed more on value creation in ecosystems. Increase in an ecosystem's value creation does not necessarily result in higher appropriated value by the actors, unless a precise value appropriation regime (Veugelers \& Cassiman, 1999) exists in the ecosystem. To this end, collective and dynamic strategies for protecting intellectual property rights are required in ecosystems. Notwithstanding a few studies (see for example, Huang et al., 2014; Hurmelinna-Laukkanen \& Puumalainen, 2007; Hurmelinna et al., 2007), the current level of knowledge regarding collaboration and ecosystem appropriability regimes remains limited.

\subsubsection{Consequences of technological and industrial convergence for ecosystem actors}

Industrial and technological convergence are not new phenomena (Athreye \& Keeble, 2000; Rosenberg, 1976). Although numerous contributions have been made on the process of convergence (Hacklin et al., 2009), including challenges in technological convergence (Jeong \& Lee, 2015), asymmetries in technological diversification (knowledge enhancement), and business portfolio diversification (Gambardella \& Torrisi, 1998), as well as other case studies for technological and industrial convergence (Geum, Kim, \& Lee, 2016; Li \& Ouyang, 2017, 2018), nevertheless, still too little is known about the consequences of industrial and technological convergence on the performance of ecosystem actors. For example, the ability to predict possible new technology fusion futures would be highly beneficial for organizational strategies or to help with the adjustment of innovation policy instruments, as a consequence of technological and industrial convergence and new waves of change in technology platforms.

\subsubsection{Applying lean thinking in ecosystems}

Although analysing ecosystems is complex and system thinking cannot easily be applied to ecosystems, there are still handy practices from systems engineering and new product development that can be applied to an ecosystems approach. Lean thinking for frugal innovation (Zeschky et al., 2011) is among such practices. The majority of papers relevant to EVCC analysed management strategies to increase EVCC in the contexts where highly competitive markets require ecosystems to have differentiation advantages through a variety of complementary solutions. The papers discussed either how mature ecosystems retain their competitive advantages or how radically innovative ecosystems emerge from disruptive technologies. There is, however, a lack of understanding about how lean manufacturing with cost reduction incentives and frugal innovation practices can bring various actors together to collectively deliver products, in particular where the main functionalities (in comparison with incumbent technologies) are included, but at a cheaper cost.

\subsubsection{Diversifying knowledge sources and analytics for systematic knowledge exploration}

Another issue to empirically address is the relationship of using different sources of information by ecosystem actors with EVCC. Although data science has long been used in both academia and industry, less attention has been paid to how all actors within ecosystems may benefit from using diverse electronically available data sets in combination with a variety of analytics techniques such as scientometrics, patentometrics, social network analysis, and text mining. The key translation requirement is how to "humanize" new value creation and capture for the mutual benefit of various actors within these combined digital and "offline" ecosystems.

Consider a wind energy ecosystem, for example, where the ecosystem consists of different types of actors in different locations including the upstream sector (basic applied research units, R\&D departments, universities, raw material providers and suppliers of wind turbine components), downstream sector (complementors facilitating the distribution and consumption of wind power, service and maintenance sector, infrastructure providers, etc.), governments, unions and associations, research funding agencies, investors, end-users, and more (Valkokari, 2015). In this ecosystem, patentometrics, social network analysis, and text mining enable industry managers to access valuable knowledge regarding technological trajectories, promising technologies, and major industry players (See for example, Castriotta \& Di Guardo, 2016; Daim et al., 2006; Kapoor et al., 2015; Ranaei et al., 2016). 


\section{Ecosystem Value Creation and Capture: A Systematic Review of Literature and} Potential Research Opportunities Behrooz Khademi

Table 4. Effective strategies and practices for EVCC

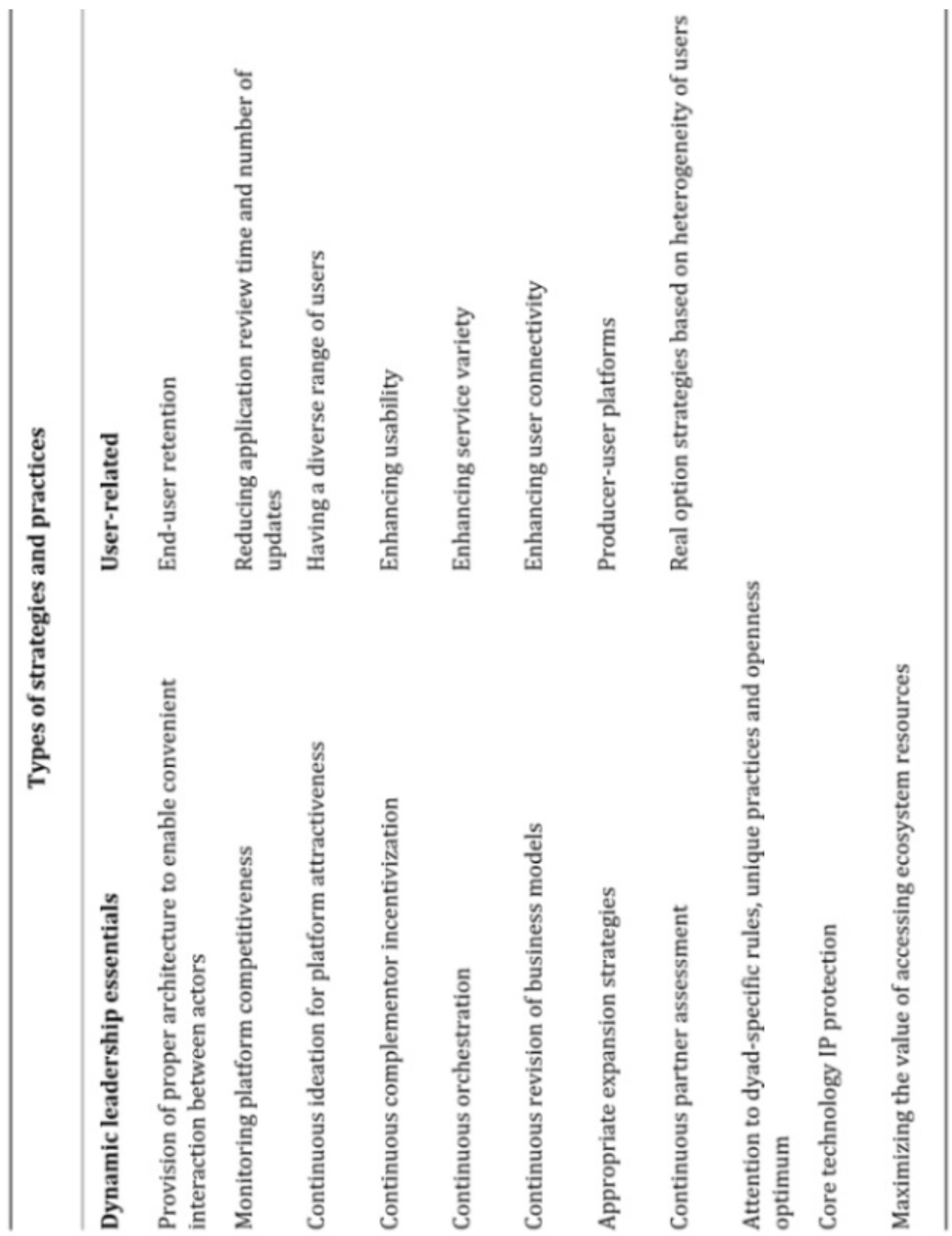




\section{Ecosystem Value Creation and Capture: A Systematic Review of Literature and} Potential Research Opportunities Behrooz Khademi

Table 4. Effective strategies and practices for EVCC (cont'd)
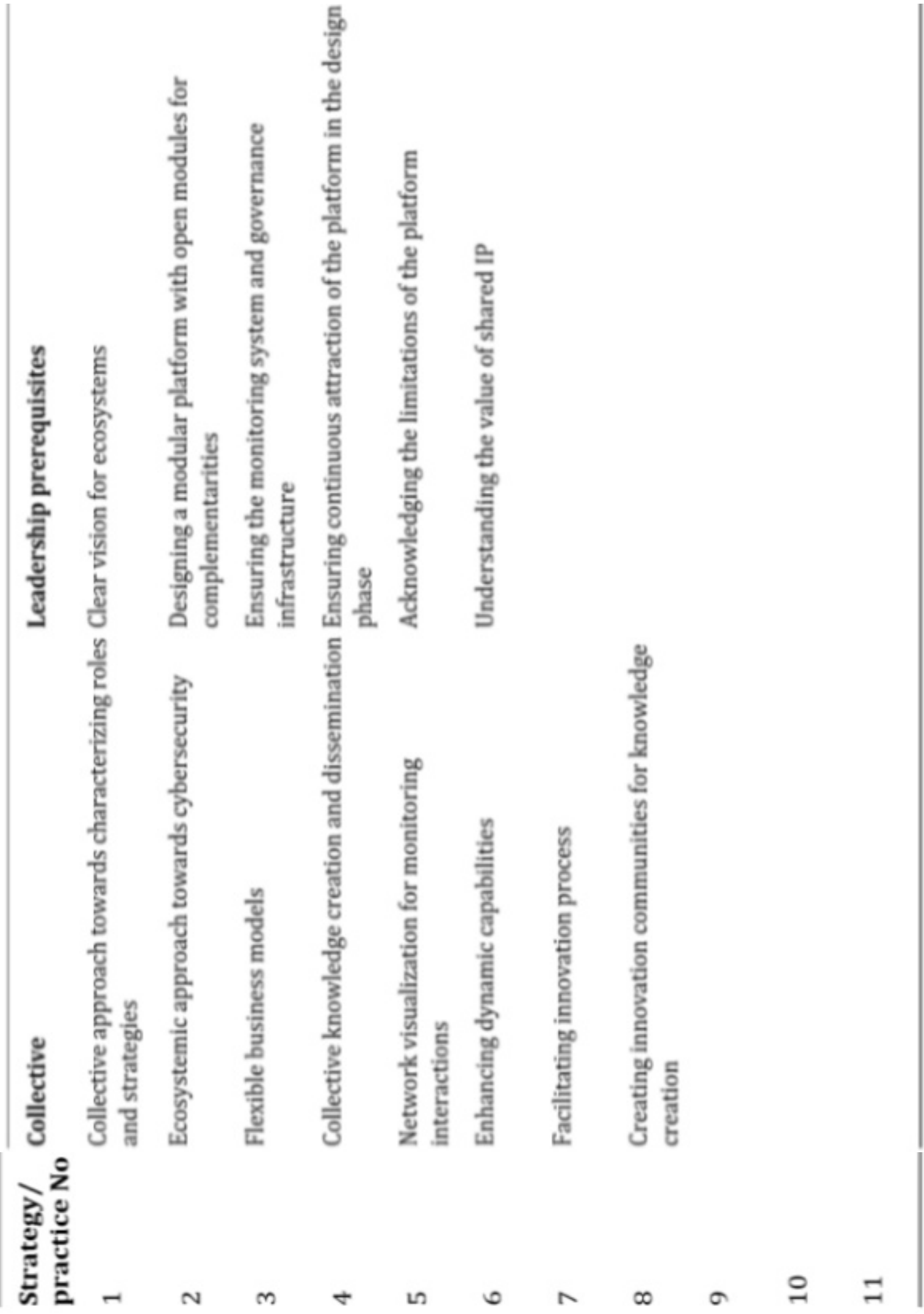


\section{Ecosystem Value Creation and Capture: A Systematic Review of Literature and Potential Research Opportunities Behrooz Khademi}

Scientometrics in combination with social network analysis and text analytics allow managers of research organizations and universities to access insightful information about the emergence of basic research in wind energy, state-of-the-art research topics and the network structure of knowledge workers and actors in wind energy research (See for example, Bonilla et al., 2015; Facin et al., 2016; Randhawa et al., 2016). Market research and consumer analytics provide market analysts and managers with valuable knowledge about the past, present, and future of technology markets in the wind energy ecosystem (See for example, Erevelles et al., 2016; Tirunillai \& Tellis, 2014).

However, these sources of knowledge must not be considered separately, but rather only together as a whole for forecasting, strategizing, or adjusting innovation policy instruments. This is because the ecosystem actors have ongoing interactions with each other and as a result the "real time" output from each of the actors' analyses of the ecosystem may be relevant to all ecosystem actors. In many cases, subscribing to most data sources required for data extraction and analysis are free of charge, or at least available to analysts and researchers at reasonable costs. Therefore, using electronically available data sets may serve to assist with reducing the amount of resources required for collecting primary data in organizations (Khademi, 2019).

\section{Discussion and Conclusion}

A recent upward trend in publishing papers relevant to EVCC has occurred in the literature. However, the contributions remain fragmented and up until now highlight several different themes of EVCC. Therefore, in this paper a systematic review of literature was conducted to shed light on the growth of EVCC studies over time (RQ1), to explore the hitherto underlying themes discussed in the scholarly research of EVCC (RQ2), and to identify potential opportunities for future research for EVCC (RQ3). In response to RQ1, the literature on ecosystems has been accommodating an increasingly growing number of research papers on EVCC. Sixty percent of the papers in the sample have been published since 2016, with $26.7 \%$ in 2018 . This finding is in line with Scaringella and Radziwon (2017) in that the number of papers relevant to ecosystems has started to significantly grow over the past few years. The International Journal of Technology Management, Research Policy, Technological Forecasting \& Social Change, and Technology Innovation Management Review have been the most popular journals among scholars in EVCC research. Scholars affiliated to American, British and Finnish organizations have showed the most interest towards EVCC research.

The results of content analysis in response to RQ2 revealed that the underlying themes in the fragmented EVCC literature were different EVCC mechanisms and their determinants, major drivers of EVCC, challenges for realising EVCC and, effective strategies and practices for EVCC. The output of the content analysis served as an input to help identify some of the remaining research puzzles in the fields of ecosystems and EVCC, hence the response to RQ3. Among the many possible future research opportunities, this study implied the potential for response to the paucity of empirical research on several areas: non-focal actors for EVCC, proper appropriability regimes in ecosystems, consequences of technological and industrial convergence for ecosystem actors, application of lean thinking in ecosystems, and diversification of knowledge sources and analytics for systematic knowledge exploration in ecosystems.

The study contributes both to academic research and practice. It extends the existing literature on the intersection of ecosystems, value creation and capture, and strategy by synthesizing the contributions on EVCC. Although other scholars have previously conducted systematic literature reviews on the co-evolution of ecosystems (Makinen \& Dedehayir, 2012), roles of different actors in the start-up phase of ecosystems (Dedehayir et al., 2018), empirical research in ecosystems (Järvi \& Kortelainen, 2017), varieties of ecosystems and their invariants (Scaringella \& Radziwon, 2017), service ecosystems (Kohtamaki \& Rajala, 2016) and, terminologies and concepts used in ecosystem literature (Aarikka-Stenroos \& Ritala, 2017; Alvedalen \& Boschma, 2017; Oh et al., 2016; Ritala \& Almpanopoulou, 2017; Stam, 2015), there has not yet been an attempt to organize and synthesize the various different studies that have focussed on and proven relevant to EVCC. Furthermore, this study contributes to theoretical knowledge by ushering forward into view some of the potential avenues for future research in ecosystems and EVCC. Managers can thereby benefit from this research irrespective of the position of their firms in ecosystem game dynamics, especially C-suite managers can use the content analysis results to aid with better strategic planning and operations management.

Similar to all academic research, this study was subject to limitations. First, due to the scholars' 


\section{Ecosystem Value Creation and Capture: A Systematic Review of Literature and Potential Research Opportunities Behrooz Khademi}

recommendations on the advantages of WoS to Google Scholar and SCOPUS for conducting review or bibliometric analyses in management studies, the data collection process was limited to extracting data only from the WoS database. Second, non-peer reviewed documents including book sections, non-peer reviewed conference papers, and non-English papers were excluded from the final sample. Although these strategies may have resulted in the absence of some relevant articles from the sample, nevertheless it included most of the relevant high-quality papers involving EVCC. Third, the opportunities identified for future research were subjective and limited to the experience of the author of this paper. Other researchers with different academic or practical experiences may have identified other missing pieces of the research puzzle that as a community we may also strive in our own way and together to complete or to solve.

\section{References}

Aarikka-Stenroos, L., \& Ritala, P. 2017. Network management in the era of ecosystems: Systematic review and management framework. Industrial Marketing Management, 67: 23-36.

https://doi.org/10.1016/j.indmarman.2017.08.010

Adner, R. 2016. Ecosystem as Structure. Journal of Management, 43(1): 39-58.

https: $/ /$ doi-

org.ezproxy.lib.rmit.edu.au/10.1177/01492063166784 51

Adner, R., \& Kapoor, R. 2010. Value Creation in Innovation Ecosystems: How the Structure of Technological Interdependence Affects Firm Performance in New Technology Generations. Strategic Management Journal, 31(3): 306-333. https://doi-

org.ezproxy.lib.rmit.edu.au/10.1002/smj.821

Alvedalen, J., \& Boschma, R. 2017. A critical review of entrepreneurial ecosystems research: towards a future research agenda. European Planning Studies, 25(6): 887-903.

https://doi-

org.ezproxy.lib.rmit.edu.au/10.1080/09654313.2017.1 299694

Ansari, S. S., Garud, R., \& Kumaraswamy, A. 2016. The disruptor's dilemma: TiVo and the U.S. television ecosystem. Strategic Management Journal, 37(9): 1829-1853.

https://doi-

org.ezproxy.lib.rmit.edu.au/10.1002/smj.2442

Athreye, S., \& Keeble, D. 2000. Technological convergence, globalisation and ownership in the UK computer industry. Technovation, 20(5): 227-245. https://doi.org/10.1016/S0166-4972(99)00135-2
Azzam, J. E., Ayerbe, C., \& Dang, R. 2017. Using patents to orchestrate ecosystem stability: the case of a French aerospace company. International Journal of Technology Management, 75(1-4): 97-120.

https://doi.org/10.1504/IJTM.2017.085695

Ben Letaifa, S. 2014. The uneasy transition from supply chains to ecosystems. Management Decision, 52(2): 278-295.

https://doi.org/10.1108/MD-06-2013-0329

Bonilla, C. A., Merigó, J. M., \& Torres-Abad, C. J. S. 2015. Economics in Latin America: a bibliometric analysis. Scientometrics, 105(2): 1239-1252.

https://doi-

org.ezproxy.lib.rmit.edu.au/10.1007/s11192-0151747-7

Borgh, M., Cloodt, M., \& Romme, A. G. L. 2012. Value creation by knowledge-based ecosystems: evidence from a field study. R\&D Management, 42(2): 150-169. https://doi-

org.ezproxy.lib.rmit.edu.au/10.1111/j.1467-

9310.2011.00673.x

Carvalho, L. M. C., \& Galina, S. V. 2015. The role of business incubators for start-ups development in Brazil and Portugal. World Journal of Entrepreneurship Management and Sustainable Development, 11(4): 256-267. https://doi.org/10.1108/WJEMSD-05-2015-0023

Castriotta, M., \& Di Guardo, M. C. 2016. Disentangling the automotive technology structure: a patent cocitation analysis. Scientometrics, 107(2): 819-837. https://doi.org/10.1007/s11192-016-1862-0

Ceccagnoli, M., Forman, C., Huang, P., \& Wu, D. J. 2012. Cocreation of Value in a Platform Ecosystem: The Case of Enterprise Software. Mis Quarterly, 36(1): 263290.

https://www.jstor.org/stable/41410417

Chen, J., Liu, X., \& hU, Y. 2016. Establishing a CoPsbased innovation ecosystem to enhance competence - the case of CGN in China. International Journal of Technology Management, 72(1/2/3): 144-170. https://doi.org/10.1504/IJTM.2016.080549

Chesbrough, H., Lettl, C., \& Ritter, T. 2018. Value Creation and Value Capture in Open Innovation. Journal of Product Innovation Management, 35(6): 930-938.

https://doi.org/10.1111/jpim.12471

Chesbrough, H. W., \& Appleyard, M. M. 2007. Open innovation and strategy. California Management Review, 50(1): 57-76.

https://doi.org/10.2307/41166416

Clarysse, B., Wright, M., Bruneel, J., \& Mahajan, A. 2014. Creating value in ecosystems: Crossing the chasm between, knowledge and business ecosystems. Research Policy, 43(7): 1164-1176.

https://doi.org/10.1016/j.respol.2014.04.014

Cozzolino, A., Verona, G., \& Rothaermel, F. T. 2018. Unpacking the Disruption Process: New Technology, Business Models, and Incumbent Adaptation. Journal of Management Studies, 55(7): 1166-1202. 


\section{Ecosystem Value Creation and Capture: A Systematic Review of Literature and Potential Research Opportunities Behrooz Khademi}

https://doi-

org.ezproxy.lib.rmit.edu.au/10.1111/joms.12352

Dagnino, G.B. and Padula, G. (2002). "Coopetition Strategy: Towards a New Kind of Interfirm Dynamics for Value Creation". EURAM 2nd Annual Conference, Stockholm School of Entrepreneurship, Sweden.

Daim, T. U., Rueda, G., Martin, H., \& Gerdsri, P. 2006. Forecasting emerging technologies: Use of bibliometrics and patent analysis. Technological Forecasting and Social Change, 73(8): 981-1012. https://doi.org/10.1016/j.techfore.2006.04.004

Dattee, B., Alexy, O., \& Autio, E. 2018. Maneuvering in Poor Visibility: How Firms Play the Ecosystem Game when Uncertainty is High. Academy of Management Journal, 61(2): 466-498.

https://doi.org/10.5465/amj.2015.0869

Dedehayir, O., Mäkinen, S. J., \& Roland Ortt, J. 2018. Roles during innovation ecosystem genesis: A literature review. Technological Forecasting and Social Change, 136: 18-29.

https://doi.org/10.1016/j.techfore.2016.11.028

Ehrenhard, M., Wijnhoven, F., van den Broek, T., \& Zinck Stagno, M. 2017. Unlocking how start-ups create business value with mobile applications: Development of an App-enabled Business Innovation Cycle. Technological Forecasting and Social Change, 115: 26-36.

https://doi.org/10.1016/j.techfore.2016.09.011

Erevelles, S., Fukawa, N., \& Swayne, L. 2016. Big Data consumer analytics and the transformation of marketing. Journal of Business Research, 69(2): 897904.

https://doi.org/10.1016/j.jbusres.2015.07.001

Facin, A. L. F., Gomes, L. A. d. V., Spinola, M. d. M., \& Salerno, M. S. 2016. The Evolution of the Platform Concept: A Systematic Review. IEEE Transactions on Engineering Management, 63(4): 475-488.

10.1109/TEM.2016.2593604

https://ieeexplore.ieee.org/document/7547254

Fulgencio, H. 2017. Social value of an innovation ecosystem: the case of Leiden Bioscience Park, The Netherlands. International Journal of Innovation Science, 9(4): 355-373.

https://doi.org/10.1108/IJIS-09-2017-0098

Gambardella, A., \& Torrisi, S. 1998. Does technological convergence imply convergence in markets? Evidence from the electronics industry. Research Policy, 27(5): 445-463.

https://doi-

org.ezproxy.lib.rmit.edu.au/10.1016/S0048-

7333(98)00062-6

Gavel, Y., \& Iselid, L. 2008. Web of Science and Scopus: a journal title overlap study. Online Information Review, 32(1): 8-21.

https://doi.org/10.1108/14684520810865958

Gawer, A., \& Cusumano, M. A. 2014. Industry Platforms and Ecosystem Innovation. Journal of Product Innovation Management, 31(3): 417-433. https://doi-

org.ezproxy.lib.rmit.edu.au/10.1111/jpim.12105
Geum, Y., Kim, M. S., \& Lee, S. 2016. How industrial convergence happens: A taxonomical approach based on empirical evidences. Technological Forecasting and Social Change, 107: 112-120.

https://doi.org/10.1016/j.techfore.2016.03.020

Hacklin, F., Marxt, C., \& Fahrni, F. 2009. Coevolutionary cycles of convergence: An extrapolation from the ICT industry. Technological Forecasting and Social Change, 76(6): 723-736.

https://doi.org/10.1016/j.techfore.2009.03.003

Haile, N., \& Altmann, J. 2016. Structural analysis of value creation in software service platforms. Electronic Markets, 26(2): 129-142.

https://doi-

org.ezproxy.lib.rmit.edu.au/10.1007/s12525-0150208-8

Hannu Tuomisaari, J., Peltonen, T. R. N., Dong, X., \& Nyman, G. 2013. Value Capture and Value Creation in High-Velocity Networked Environments. 2013 IEEE International Conference on Service Operations and Logistics, and Informatics. Dongguan, China: IEEE.

Helfat, C. E., \& Raubitschek, R. S. 2018. Dynamic and integrative capabilities for profiting from innovation in digital platform-based ecosystems. Research Policy, 47(8): 1391-1399.

https://doi.org/10.1016/j.respol.2018.01.019

Herskovits, R., Grijalbo, M., \& Tafur, J. 2013. Understanding the main drivers of value creation in an open innovation program. International Entrepreneurship and Management Journal, 9(4): 631640.

https://doi-

org.ezproxy.lib.rmit.edu.au/10.1007/s11365-013$0267-2$

Hienerth, C., Lettl, C., \& Keinz, P. 2014. Synergies among Producer Firms, Lead Users, and User Communities: The Case of the LEGO Producer-User Ecosystem. Journal of Product Innovation Management, 31(4): 848-866.

https://doi-

org.ezproxy.lib.rmit.edu.au/10.1111/jpim.12127

Hooge, S., \& Le Du, L. 2016. Collaborative Organizations for Innovation: A Focus on the Management of Sociotechnical Imaginaries to Stimulate Industrial Ecosystems. Creativity and Innovation Management, 25(3): 311-330.

https://doi-

org.ezproxy.lib.rmit.edu.au/10.1111/caim.12179

Huang, F., Rice, J., Galvin, P., \& Martin, N. 2014. Openness and Appropriation: Empirical Evidence From Australian Businesses. IEEE Transactions on Engineering Management, 61(3): 488-498.

https://doi.org/10.1109/TEM.2014.2320995

Huber, T. L., Kude, T., \& Dibbern, J. 2017. Governance Practices in Platform Ecosystems: Navigating Tensions Between Cocreated Value and Governance Costs. Information Systems Research, 28(3): 563-584. https://doi.org/10.1287/isre.2017.0701

Hurmelinna-Laukkanen, P., \& Puumalainen, K. 2007. Formation of the appropriability regime: Strategic 


\section{Ecosystem Value Creation and Capture: A Systematic Review of Literature and Potential Research Opportunities Behrooz Khademi}

and practical considerations. Innovation, 9(1): 2-13. https://doi-

org.ezproxy.lib.rmit.edu.au/10.5172/impp.2007.9.1.2

Hurmelinna, P., Kyläheiko, K., \& Jauhiainen, T. 2007. The Janus face of the appropriability regime in the protection of innovations: Theoretical re-appraisal and empirical analysis. Technovation, 27(3): 133-144. https://doi.org/10.1016/j.technovation.2005.09.011

Ikävalko, H., Turkama, P., \& Smedlund, A. 2018. Value Creation in the Internet of Things: Mapping Business Models and Ecosystem Roles. Technology Innovation Management Review, 8(3): 5-15.

http://doi.org/10.22215/timreview/1142

Jacobides, M. G., Cennamo, C., \& Gawer, A. 2018. Towards a theory of ecosystems. Strategic Management Journal, 39(8): 2255-2276.

https:1/doi-

org.ezproxy.lib.rmit.edu.au/10.1002/smj.2904

Jacobides, M. G., \& Tae, C. J. 2015. Kingpins, Bottlenecks, and Value Dynamics Along a Sector. Organization Science, 26(3): 889-907.

https://doi.org/10.1287/orsc.2014.0958

Järvi, K., Almpanopoulou, A., \& Ritala, P. 2018. Organization of knowledge ecosystems: Prefigurative and partial forms. Research Policy, 47(8): 1523-1537. https://doi.org/10.1016/j.respol.2018.05.007

Järvi, K., \& Kortelainen, S. 2017. Taking stock of empirical research on business ecosystems: a literature review. International Journal of Business and Systems Research, 11(3): 215.

https://doi.org/10.1504/IJBSR.2017.085469

Jeong, S., \& Lee, S. 2015. What drives technology convergence? Exploring the influence of technological and resource allocation contexts. Journal of Engineering and Technology Management, 36: 78-96.

https://doi.org/10.1016/j.jengtecman.2015.05.004

Kapoor, R. 2013. Collaborating with Complementors: What Do Firms Do? Collaboration and Competition in Business Ecosystems, 30: 3-25.

https://doi.org/10.1108/S0742-

3322(2013)0000030004

Kapoor, R., Karvonen, M., Ranaei, S., \& Kässi, T. 2015. Patent portfolios of European wind industry: New insights using citation categories. World Patent Information, 41: 4-10.

https://doi.org/10.1016/j.wpi.2015.02.002

Khademi, B. 2019. The Ecosystem Knowledge Explorer: A Tool to Systematically Discover External Knowledge. Technology Innovation Management Review, 9(7).

http://doi.org/10.22215/timreview/1253

Kim, D. 2016. Value ecosystem models for social media services. Technological Forecasting and Social Change, 107: 13-27.

https://doi.org/10.1016/j.techfore.2016.03.010

Kohtamaki, M., \& Rajala, R. 2016. Theory and practice of value co-creation in $\mathrm{B} 2 \mathrm{~B}$ systems. Industrial Marketing Management, 56: 4-13. https://doi.org/10.1016/j.indmarman.2016.05.027

Kude, T., Dibbern, J., \& Heinzl, A. 2012. Why Do Complementors Participate? An Analysis of Partnership Networks in the Enterprise Software Industry. IEEE Transactions on Engineering Management, 59(2): 250-265.

https://doi.org/10.1109/Tem.2011.2111421

Kumaraswamy, A., Garud, R., \& Ansari, S. 2018. Perspectives on Disruptive Innovations. Journal of Management Studies, 55(7): 1025-1042.

https://doi.org/10.1111/joms.12399

Laursen, K., \& Salter, A. J. 2014. The paradox of openness: Appropriability, external search and collaboration. Research Policy, 43(5): 867-878. https://doi.org/10.1016/j.respol.2013.10.004

Leten, B., Vanhaverbeke, W., Roijakkers, N., Clerix, A., \& Van Helleputte, J. 2013. IP Models to Orchestrate Innovation Ecosystems: IIMEC, a Public Research Institute in Nano-Electronics. California Management Review, 55(4): 51-64.

https://doiorg.ezproxy.lib.rmit.edu.au/10.1525/cmr.2013.55.4.5 1

Li, H., \& Ouyang, T. 2017. The computation of boundary spanning for the IT-enabled commercial ecosystem. Cluster Computing, 20(4): 3085-3098. https://doiorg.ezproxy.lib.rmit.edu.au/10.1007/s10586-0170994-1

Li, H., \& Ouyang, T. 2018. Boundary spanning strategies of internet companies in the context of big data. Multimedia Tools and Applications.

https://doiorg.ezproxy.lib.rmit.edu.au/10.1007/s11042-018$5643-\mathrm{z}$

Li, Y. R. 2009. The technological roadmap of Cisco's business ecosystem. Technovation, 29(5): 379-386. https://doi.org/10.1016/j.technovation.2009.01.007

Luo, J. X., \& Triulzi, G. 2018. Cyclic dependence, vertical integration, and innovation: The case of Japanese electronics sector in the 1990s. Technological Forecasting and Social Change, 132: 46-55. https://doi.org/10.1016/j.techfore.2017.12.009

Makinen, S. J., \& Dedehayir, O. 2012. Business ecosystem evolution and strategic considerations: A literature review. Paper presented at the 2012 18th International ICE Conference on Engineering, Technology and Innovation.

10.1109/ICE.2012.6297653

Mäkinen, S. J., Kanniainen, J., \& Peltola, I. 2014. Investigating Adoption of Free Beta Applications in a Platform-Based Business Ecosystem. Journal of Product Innovation Management, 31 (3): 451-465.

https://doi-

org.ezproxy.lib.rmit.edu.au/10.1111/jpim.12107

Mantovani, A., \& Ruiz-Aliseda, F. 2016. Equilibrium Innovation Ecosystems: The Dark Side of Collaborating with Complementors. Management Science, 62(2): 534-549.

http://dx.doi.org/10.2139/ssrn.2050969 


\section{Ecosystem Value Creation and Capture: A Systematic Review of Literature and Potential Research Opportunities Behrooz Khademi}

Moore, J. F. 1993. Predators and prey: a new ecology of competition. Harvard Business Review, 71(3): 75-86.

Morgan, L., Feller, J., \& Finnegan, P. 2013. Exploring value networks: theorising the creation and capture of value with open source software. European Journal of Information Systems, 22(5): 569-588.

https://doi-

org.ezproxy.lib.rmit.edu.au/10.1057/ejis.2012.44

Ngongoni, C. N., Grobbelaar, S., \& Schutte, C. 2017. The Role of Open Innovation Intermediaries in Entrepreneurial Ecosystems Design. South African Journal of Industrial Engineering, 28(3).

https://doi.org/10.7166/28-3-1839

Oh, D. S., Phillips, F., Park, S., \& Lee, E. 2016. Innovation ecosystems: A critical examination. Technovation, 54: $1-6$.

https://doi.org/10.1016/j.technovation.2016.02.004

Oh, J., Koh, B., \& Raghunathan, S. 2015. Value appropriation between the platform provider and app developers in mobile platform mediated networks. Journal of Information Technology, 30(3): 245-259.

https://doi-

org.ezproxy.lib.rmit.edu.au/10.1057/jit.2015.21

Papert, M., \& Pflaum, A. 2017. Development of an Ecosystem Model for the Realization of Internet of Things (IoT) Services in Supply Chain Management. Electronic Markets, 27(2): 175-189.

https://doi-

org.ezproxy.lib.rmit.edu.au/10.1007/s12525-017-

0251-8

Parker, G., Van Alstyne, M., \& Jiang, X. Y. 2017. Platform Ecosystems: How Developers Invert the Firm. Mis Quarterly, 41(1).

http://dx.doi.org/10.2139/ssrn.2861574

Pellikka, J., \& Ali-Vehmas, T. 2016. Managing Innovation Ecosystems to Create and Capture Value in ICT Industries. Technology Innovation Management Review, 6(10): 17-24.

http://doi.org/10.22215/timreview/ 1024

Pitelis, C. N. 2009. The Co-Evolution of Organizational Value Capture, Value Creation and Sustainable Advantage. Organization Studies, 30(10): 1115-1139. https://doi-

org.ezproxy.lib.rmit.edu.au/10.1177/01708406093469 77

Prins, A. A. M., Costas, R., van Leeuwen, T. N., \& Wouters, P. F. 2016. Using Google Scholar in research evaluation of humanities and social science programs: A comparison with Web of Science data. Research Evaluation, 25(3): 264-270. https://doi.org/10.1093/reseval/rvv049

Radziwon, A., Bogers, M., \& Bilberg, A. 2017. Creating and capturing value in a regional innovation ecosystem: a study of how manufacturing SMEs develop collaborative solutions. International Journal of Technology Management, 75(1-4): 73-96.

https://ssrn.com/abstract=3204313

Ranaei, S., Karvonen, M., Suominen, A., \& Kässi, T. 2016. Patent-based technology forecasting: case of electric and hydrogen vehicle. International Journal of Energy Technology and Policy, 12(1): 20-40.

https://doi.org/10.1504/IJETP.2016.074490

Randhawa, K., Wilden, R., \& Hohberger, J. 2016. A Bibliometric Review of Open Innovation: Setting a Research Agenda. Journal of Product Innovation Management, 33(6): 750-772.

https://doi.org/10.1111/jpim.12312

Rietveld, J., \& Eggers, J. P. 2018. Demand Heterogeneity in Platform Markets: Implications for Complementors. Organization Science, 29(2): 304322.

http://dx.doi.org/10.2139/ssrn.2714366

Ritala, \& Gustafsson, R. 2018. Q\&A. Innovation and Entrepreneurial Ecosystem Research: Where Are We Now and How Do We Move Forward? Technology Innovation Management Review, 8(7).

http://doi.org/10.22215/timreview/1171

Ritala, P., Agouridas, V., Assimakopoulos, D., \& Gies, O. 2013. Value creation and capture mechanisms in innovation ecosystems: a comparative case study. International Journal of Technology Management, 63(3-4): 244-267.

https://doi.org/10.1504/IJTM.2013.056900

Ritala, P., \& Almpanopoulou, A. 2017. In defense of 'eco' in innovation ecosystem. Technovation, 60-61: 39-42. https://doi.org/10.1016/j.technovation.2017.01.004

Rong, K., Patton, D., \& Chen, W. 2018. Business models dynamics and business ecosystems in the emerging 3D printing industry. Technological Forecasting and Social Change, 134: 234-245.

https://doi.org/10.1016/j.techfore.2018.06.015

Rosenberg, N. 1976. Perspectives on Technology. Cambridge: Cambridge University Press.

Scaringella, L., \& Radziwon, A. 2017. Innovation, entrepreneurial, knowledge, and business ecosystems: Old wine in new bottles? (article in press). Technological Forecasting and Social Change. https://doi-

org.ezproxy.lib.rmit.edu.au/10.1016/j.techfore.2017.0 9.023

Song, P., Xue, L., Rai, A., \& Zhang, C. 2018. The Ecosystem of Software Platform: A Study of Asymmetric Cross-Side Network Effects and Platform Governance. MIS Quarterly, 42(1): 121-A126.

https://ssrn.com/abstract $=2568817$

Spena, T. R., Trequa, M., \& Bifulco, F. 2016. Knowledge Practices for an Emerging Innovation Ecosystem. International Journal of Innovation and Technology Management, 13(5): 1640013.

https://doi.org/10.1142/S0219877016400137

Stam, E. 2015. Entrepreneurial Ecosystems and Regional Policy: A Sympathetic Critique. European Planning Studies, 23(9): 1759-1769.

https://doi-

org.ezproxy.lib.rmit.edu.au/10.1080/09654313.2015.1 061484

Still, K., Huhtamaki, J., Russell, M. G., \& Rubens, N. 2014. Insights for orchestrating innovation 


\section{Ecosystem Value Creation and Capture: A Systematic Review of Literature and Potential Research Opportunities Behrooz Khademi}

ecosystems: the case of EIT ICT Labs and data-driven network visualisations. International Journal of Technology Management, 66(2-3): 243-265.

https://doi.org/10.1504/IJTM.2014.064606

Suominen, A., Seppänen, M., \& Dedehayir, O. 2019. A bibliometric review on innovation systems and ecosystems: a research agenda. European Journal of Innovation Management, $0(0)$.

https://doi.org/10.1108/EJIM-12-2017-0188

Takey, S. M., \& Carvalho, M. M. 2016. Fuzzy front end of systemic innovations: A conceptual framework based on a systematic literature review. Technological Forecasting and Social Change, 111: 97-109. https://doi.org/10.1016/j.techfore.2016.06.011

Tanev, G., Tzolov, P., \& Apiafi, R. 2015. A Value Blueprint Approach to Cybersecurity in Networked Medical Devices. Technology Innovation Management Review, 5(6).

http://doi.org/10.22215/timreview/903

Tee, R., \& Gawer, A. 2009. Industry architecture as a determinant of successful platform strategies: a case study of the i-mode mobile Internet service. European Management Review, 6(4): 217-232.

https://doi.org/10.1057/emr.2009.22

Teece, D. J. 2018. Profiting from innovation in the digital economy: Enabling technologies, standards, and licensing models in the wireless world. Research Policy, 47(8): 1367-1387.

https://doi.org/10.1016/j.respol.2017.01.015

Tellier, A. 2017. Whatever happened to the 'great escape'? Lessons from the rise and decline of the pinball ecosystem. International Journal of Technology Management, 75(1-4): 121-141. https://doi.org/10.1504/IJTM.2017.085691

Tirunillai, S., \& Tellis, G. J. 2014. Mining Marketing Meaning from Online Chatter: Strategic Brand Analysis of Big Data Using Latent Dirichlet Allocation. Journal of Marketing Research, 51(4): 463-479.

https://doi.org/10.1509/jmr.12.0106

Toh, P. K., \& Miller, C. D. 2017. Pawn to Save a Chariot, or Drawbridge Into the Fort? Firms' Disclosure During Standard Setting and Complementary Technologies Within Ecosystems. Strategic Management Journal, 38(11): 2213-2236.

https://doi.org/10.1002/smj.2655

Toma, A., Secundo, G., \& Passiante, G. 2018. Open innovation and intellectual property strategies: Empirical evidence from a bio-pharmaceutical case study. Business Process Management Journal, 24(2): 501-516.

https://doi.org/10.1108/BPMJ-11-2016-0230

Tura, N., Kutvonen, A., \& Ritala, P. 2018. Platform design framework: conceptualisation and application. Technology Analysis \& Strategic Management, 30(8): 881-894. https://doi.org/10.1080/09537325.2017.1390220

Valkokari, K. 2015. Business, Innovation, and Knowledge Ecosystems: How They Differ and How to Survive and Thrive within Them. Technology Innovation Management Review: 17-24. http://doi.org/10.22215/timreview/919

Valkokari, K., Seppanen, M., Mantyla, M., \& Jylha-Ollila, S. 2017. Orchestrating Innovation Ecosystems: A Qualitative Analysis of Ecosystem Positioning Strategies. Technology Innovation Management Review, 7(3): 12-24.

http://doi.org/10.22215/timreview/1061

Vasconcelos Gomes, L. A. d., Salerno, M. S., Phaal, R., \& Probert, D. R. 2018. How entrepreneurs manage collective uncertainties in innovation ecosystems. Technological Forecasting and Social Change, 128: 164-185.

https://doi.org/10.1016/j.techfore.2017.11.016

Veugelers, R., \& Cassiman, B. 1999. Make and buy in innovation strategies: evidence from Belgian manufacturing firms. Research Policy, 28(1): 63-80. https://doi.org/10.1016/S0048-7333(98)00106-1

Visnjic, I., Neely, A., Cennamo, C., \& Visnjic, N. 2016. Governing the City: Unleashing Value from the Business Ecosystem. California Management Review, 59(1): 109-140.

https://doi.org/10.5465/ambpp.2015.17397abstract

Williamson, P. J., \& De Meyer, A. 2012. Ecosystem Advantage: How to successfully harness the power of partners. California Management Review, 55(1): 2446.

https://doi.org/10.1525/cmr.2012.55.1.24

Zeschky, M., Widenmayer, B., \& Gassmann, O. 2011. Frugal Innovation in Emerging Markets. ResearchTechnology Management, 54(4): 38-45.

https://doi.org/10.5437/08956308X5404007

\section{About the Author}

Behrooz Khademi is a PhD Candidate in Technology and Innovation Management at Royal Melbourne Institute of Technology (RMIT) in Melbourne, Australia. He received his BSc degree in Production and Manufacturing Engineering from the National Technical University of Ukraine in Kiev, Ukraine, and his MSc degree in Industrial Engineering and Management from Lappeenranta University of Technology in Lappeenranta, Finland. His research focuses on value creation, value capture, and knowledge management in ecosystems. He applies a variety of scientometric, patentometric, and text mining methods in his research.

Citation: Khademi, K. 2020. Ecosystem Value Creation and Capture: A Systematic Review of Literature and Potential Research Opportunities. Technology Innovation Management Review, 10(1): 16-34.

http://doi.org/10.22215/timreview/1311

(cc) BY

Keywords: Ecosystem, value creation, value capture, strategy, systematic literature review 